\title{
ARCHITECTURE THROUGH SPORT
}

\section{A B S T R A C T}

We can find certain parallelism between architecture and sport in history (Rome) and in contemporaneity with spectacular sport as most global kind of entertainment, and recognizable sport architecture as sign of its universal presence. London Olympic Games 2012 followed slogan „Architecture for Humanity”, adding ecological and social concern to more traditional idea of sport objects as modern cathedrals. Sport architecture has become a statement, and it embodies ideology which turns sport into reason for hope. Sport architecture is created on the field where standardization of space (and time) exists for more than hundred years, together with concentration of power in sport associations which, during these hundred years, changed their identity from civil society movements into capital enterprise institutions. Original meaning of "sport" (desportes, deport) as activity deported beyond regular and ordinary everyday life was extended into new region of space and time where mass media entertainment is produced. Contemporary sport architecture has to follow specifically sport rules for playground space, and rules of media presence. Sport places are spaces where massive audience watches the game, and were it watches itself watching - to be seen by massive media audience whose virtual presence is perhaps today the most important concern of architectural design for sport.

KEY WORDS

SPORT ARCHITECTURE

GLOBALITY

STANDARDIZATION OF SPACE

DEPORTATION

MASSIVE AUDIENCE

MEDIA PRESENCE 
During the last fifty years, sport has become a global phenomenon. So has architecture. Global is not the same as international: it is not managed by nation states system exclusively. And it is not just a refreshed version of "international style". It might be risky to try recognizing "global style" in these two omnipresent signs of unified earthly empire. What there is without any doubt is global competition: citius, altius, fortius. In this competition, there are no preordained hierarchies: Qatar can prevail over United States of America, and West Indies can beat Great Britain at its own game. No authoritative center exists, but symbolic power of world's unification is felt both in architecture and in sport.

We can find similar parallelism between architecture and sport in history. Ancient Rome, step by step conquering the Mediterranean region and beyond, spreading around the recognizable pattern of imperial architecture, and the system of games which expanded even more than Rome's territorial reach. ${ }^{1}$ At the beginning, games were something important for Rome's identity, but rare and special, organized just few times a year. At the end, in calendar there were more festive days for games than the ordinary ones. At their start, the games were popular, but humble spectacles, if compared with excessive magnitude and cost they reached when the Empire was powerful, and later, when it was already in decay. Rome conquered other nations and cultures, but left them to live with their culture after they were believed to be powerless enough. Rome's hegemony, i.e. rule without permanent use of pressure and violence, consisted of few constant pillars, and one of them were greater and more and more numerous spectacles staged in monumental buildings. Initially, as Lukian has it, spectacles were multiplied to keep poor Roman populus in good mood, but they served for all the other peoples as well, especially after all grown up men in the Empire became Roman citizens from 212 on. $^{2}$ Presence of spectacles and of imperial architecture was a sign of power, and symbolic sign of control over life itself. This sign was inviting, attractive and popular, which means that it served its purpose very well, much better than any possible kind of oppressive Romanization. With the first emperors, spectacles became privilege of state and of the emperor personally: many of them, especially the gladiator games in amphitheaters, became completely monopolized and personalized by the emperor himself. The games, together with a system of buildings for them, spread all over the country to allow each and every inhabitant to have one of them within easy reach and were a tool of hegemony and of governance. ${ }^{3}$

Today, sport and sport architecture are everywhere, and their presence is a sign of belonging to global unified civilization. Stadiums are the most visible and visited places everywhere around the world. ${ }^{4}$ It is possible not to have a museum, but not to have a place for sports would be a sign of real backwardness. The sport network is spread all around the world. The International Olympic Committee 
has 68 global sport federations included and 204 National Olympic Committees in member states; FIFA has 209 national football associations as its members. Currently, there are 193 members of the United Nations, which makes sport associations and football associations among them more international and global than any other organized relationship of global human race. Sport has become one of signs of the presence of global unity, and the symbol of unified global culture. This includes recognizable patterns of sport architecture all around the world. Not as a kind of imperial style, because there are less monumental stadiums, as Sir John Guise Sport Stadium built and donated by China to Port Moresby of Papua New Guinea for the 1991 South Pacific Games (which still can host 50.000 spectators), and more monumental ones, as Rungrado May Day Stadium in Pyongyang where, beside national football team and sporadic athletic competitions, it is the place of Arirang festival which honors Kim IlSung's birthday each April with a month long gymnastic exercises performed with precision and colorful movement of masses of people - something well known to those who still remember Tito's birthday - The Day of Youth festivals at The Yugoslav People's Army Stadium in Belgrade on May 25..$^{5}$ Of course, there is also a huge number of other sport facilities and buildings, not all of them architecturally meaningful or great, but in ideal competition they all have their place at the chart which shows a growing network of unified and standardized appearance of sport and its specially designed spaces and places.

The recent crisis and a bit older ecological and ethical concerns have changed sport architecture in at least two aspects. One aspect is that there is a move from eternal monumentality which often becomes a desert after a big event has passed by to temporary structures which can partly or completely disappear or turn into "multifunctional" ones. They are not made for one use only. As flexible and complex structures, these sport facilities are functional, but not as a kind of traditional "purity": what they want to achieve is social response which accepts them. Another one brings understanding of sport and its architecture as a space of alternative culture or at least a place of difference from ordinary life. This alternative is neither radical nor revolutionary; it is just creation of space which is on the other side of competing individualisms and different from troubled communion of labor and capital. This two-fold change has a slogan: "Architecture for humanity". It is reflected in London 2012 Olympic Games architecture which is predominantly simple and built without desire to excel and perplex. With two exceptions to the rule: Aquatic Center (Zaha Hadid Architects) and Velopark (Hopkins Architects) planned to become permanent buildings for municipal recreational use. But even they, quite attractive and monumental, have to pay tribute to demand of low energy costs and overall ecological concerns. Their sport use is different (cycling, BMXs competition; swimming, diving etc.), 
but they have something else in common: simple symbolic structure; in case of Aquatic Center it is the water wave, in case of Velopark it is velodrome cycling curve. It already got a popular name: "The Pringle". Different sources of symbolic shape but the result is quite similar. Still, these symbolic structures would like to express Coubertin's idea that what we need are cathedrals of sport, because they have to become new targets of mass pilgrimage, and because they represent a place of hope. Here, ethical concerns of sport are directly translated into aesthetic result: beautiful efficiency, where everything is designed ergonomically, ecologically and on friendly terms with its surroundings (people and nature included) and financially sustainable. That is what is meant by contemporary functional architecture: it is not just adapted to immediate function but it has to show many social functional concerns, and at the same time offer sport as parttime solution to most if not all of contemporaneity troubles. Charles Jencks ${ }^{6}$, visiting the Olympic Village (which, as usual, should become new London neighborhood after the Games), disappointed by the main stadium but thrilled by Aquatic Center and Velopark, said that it was nice to see that London and England decided to use Olympic Games and their architecture for Europeization and egalitarianism. He may be right or wrong, but sport architecture has become a statement and more than a statement: embodied ideology which turns sport into reason for hope in times when there are not many other reasons. This kind of ideology is not aggressive as physical culture and sport ideologies used to be in times of nationalism, militarism and/or totalitarianism. Aesthetically speaking, this ideology, when confronted with realities of elite sport or inaccessibility of sport and health culture to most people, sounds sleazy but not aggressive.

Of course, these grandiose buildings are just the tops of the iceberg, with hundreds of sport halls and other sport and recreational facilities built for schools, municipalities and other institutions, but also they mark the trend, and this trend is global.

But how can something like sport become global, unified, and omnipresent and even an object of special type of architecture which makes our global culture recognizable and sport something typically universal and monumental? And what power is symbolized by global sport and its architecture?

\section{MASSIVE AND FINE}

First and obvious condition, typical for sport during the last hundred years, is standardization of space. There are certain rules which determine how each kind of sport has to be practiced, including playground measures. There are other rules which apply, like those of security, as in other public buildings, but these 
are determined by state authorities mostly. Standard shape of sport playground is, however, determined by sport authorities, and is the same for any place on the Earth. For most important international competitions these rules include even more prescripts which go well beyond measurements of their playgrounds and determine number of seats, comfort for athletes and judges and journalists and general audience, accessibility, and facilities for grand media coverage. Those sports which do not have global authority with power to standardize their rules all around the globe, all facilities included, are not members of "the family". Standardization of organization of space and of its functionality has reached much higher level than any other rules and prescripts, for instance those for theaters or museums, hospitals and even airports.

This leads to another condition, that of concentration of power. There is no global standardization, including guidelines for global architecture, without global power to install and sustain equal rules for sport games all around the world, with comparability of results but also with ability to judge, punish and regulate, to manage and to sign good contracts. This power grew from a situation when in different localities different sports were played, rules were loose and negotiable and there were no authorities above single competition. Basic entity was sport club, and from there on, during the last 150 years, local, national, and finally continental and global associations were constituted step by step. This pyramid is extremely hierarchical if examined from civil society access, but also extremely flexible if approached from business side. No other part of culture accepted prescriptions of market and media orientation so willingly and so completely in short period of time. Sport was the first domain to install global concentration of power constructed from national civil societies' organizations into global institutions with all prerogatives of independent and sovereign power but without genuine internationality which can be constructed by nation states only. At sport field the sport law governs as much as it concerns game itself but some out-of-game concerns too. For instance, universal anti-doping control is done everywhere according to sport associations guidelines and rules including out-of-competition control and even anti-racism rules for behavior of audiences are modeled according to international associations and Olympic Committee prescriptions. Concentration of power in sport created certain state of exception: spaces where legal and capital power belongs to civil society associations and not only to nation state authorities. This does not mean that things did not change considerably from the first days when sport was more or less completely in hands of clubs, athletes, veteran athletes and those who helped them with sponsorship. If hundred years ago sport power emerged from civil society associationism, now it resides within capital flow. Ancient sport management consisted of veteran athletes and representatives of fans; nowadays, sport associations and clubs 
are governed by capital management. Sport associations, sport clubs and sport recreation: they are all now part of management of capital and their organization changed into post-industrial quasi civil society surplus value enterprise. Nation state authorities and local political power enter this field with taxpayer's money to produce development effects, share the glory of sport festivals and achieve much cherished sport victories for their national and local communities. They fight to become politically influential but have to accept sport associations rules even in that respect, as proved by conflict over Bosnia and Herzegovina football association leadership which was not allowed to apply "Dayton" idea of giving presidential position to representative of each entity for a while during one term. For the sake of national success and to prevent expulsion they had to obey global FIFA and UEFA law and change their football constitution, which in this country could never happen in any other domain. No Dayton in sport.

Sport, however, is not just elite sport covered by global media attention. Looked upon from this point of view, it resembles proverbial icebergs which have much more of their structure hidden below water. One of important features of this massive structure is mass itself. Mass is not just any grouping of people, not even if they appear in great numbers. Mass is a huge group of people representing all strata of population, a mixture of different classes, sexes, ages, ethnic and national groups, races etc. Mass is non-stratified appearance of otherwise stratified society and sport is very good opportunity for masses because it is on the other side of ordinary life with its divisions and grouping. This mixture, a typical product of modernity, is at the same time the nightmare of modern order, believed to be inclined to excess and explosion. ${ }^{7}$ In high culture, even during democratization of culture as official politics, mass groupings were prevented or put into framework of some kind of regulation. To regulate sport masses, all kinds of regulations were introduced, including architectural set-up and actual fences. Architectural rules now include urbanization of whole areas around greatest sport objects, including special access corridors where different parts of audience are isolated in their approach to events and complete turn-around in presence of masses at objects themselves. In the old times, some fifty years ago, fans were concentrated around playground, more or less in touch with players, while socially privileged parts of public were watching from a greater distance and height. New sport objects do not allow for direct contact between audience and sport field and put most privileged people near playground while "masses" are under supervision and control, isolated in their special segments and sectors. But, for sport, massive presence of people has another characteristics as well: that of huge number of real and potential consumers who practice sport and therefore buy sport requisites, come to sport events as those who consume even more than proverbial urban one-day guests and are ready to pay for healthy image sport as 
way of life offers. What now already ancient Hugh Hefner's "Playboy" and even his later follower "Playgirl" propagated is that play is first sport and then sex and other pleasures: one has to look good and healthy, or, one has to pretend it. ${ }^{8}$

This change of social structure on stadiums for mass sport entertainment was facilitated by another characteristic which is mentioned in connection with contemporary sport from the early days of mediatization and on. ${ }^{9}$ Today, easy accessible sport programs are everywhere in virtual space, in every home, at anybody's desk(top). Experience of sport at the spot became closer to that of theatre: to share the same physical space is the elite difference if compared with plebeian and ordinary being plugged-in by media, where you can get much more visual and other information, special support by image and voice to make even most dull events sensational and get connected with movement from perspectives which are out of reach for those physically present at the event. One of the results of this change was that fans ("real fans", as they would define themselves as opposed to those who watch from their armchairs) are now the prevailing part of sport audience at the spot, another is that sport facilities and buildings are planned and executed with much more care about visitors' comfort - and comfort of media (especially accessibility and visibility for cameras and infrastructural support), with a consequence that physically present audience appears as "representative" group for those watching from media distance, which turned spectators on the spot into theatrical group appearing on TV, similar to those who applaud or laugh at sitcoms and other TV programs (or, if we want to get atavistic, to ancient Greek chorus). But those who laugh at TV sitcoms are usually invisible whereas sport spectators appear. The whole sport facility with its architectural support is now a stage. This is the most important change for sport because all mediatized sports changed their rules to make themselves both more watchable from the armchair and more theatrical in their physical presence. New sport architecture has to support this total staging of the event, players and audience included. And it appears itself as monumental background, at moments as the front even as with the help of air view used at the biggest events to create a feeling of monumentality and importance. As a result, even architecture is made not just for the beholder who approaches and occupies the building. It is created for the eye of the camera much more than any other kind of architecture. Is there any kind of architecture to appear as globally and as often as sport architecture? Not even White House or Bilbao museum can compete with football stadiums and grand halls of spectacle.

Standardized global models, concentration of (civil society, state and international) power, mass entertainment with need to control public space and public response and total mediatization: all these together are circumstances quite favorable for architectural approach, but less open for experiments and 
postmodern manifold architectural languages: even oil station can survive with postmodern architecture's approach, including mazes, mirroring and mixture of languages, but sport premises cannot. Starting from the field which has to be done according to the rules, things are functionally defined, but this functionality does not have to be minimization of space and its shapes to bare functionality as in functionalism. Quite contrary, monumentality now goes together with comfort and visual pleasure. Taken all together, sport architecture is expected to support and make appearance of sport and sport events co-operate as massive and fine at the same time.

Where did this massive and fine sport arrive from historically?

\section{DEPORTATION}

Word sport is the English form developed from older French and other Roman languages de(s)portes, from Latin deportare, a member of well-developed family which today includes port, import and export, transport, support, deportation and many others. How can sport and deportation belong to the same roots? Initially there is a verb, a movement which involves carrying from one side to another, across dividing line and which, however, has its opening which allows for passage. It involves, of course, a change of location, but together with a change of location it involves a change of regime as well: for better or for worse. In deportation, obviously, change for the worse prevailed, and it now means that a person was expelled from its "home" somewhere else against his or her will, and was put under control of special regime, usually administered by the nation state. It is not a situation, as that of exile, but movement from one regime to another. It is similar with sport/de(s)portes: it denotes those pastimes and practices which cannot enter the territory of ordinary life. Ordinary life is life put under certain order, usually supported by legislation and always administered by power of some kind. To be inside space of administered order is safe but less free. Outside the space of administered order are those activities which are not allowed to enter the space where power reigns but are allowed to go on beyond its limits. This was a case of the theater in Shakespeare's time: it was not allowed inside city walls, so it had to exist on the other side of the Thames, where all other sports from prostitution to May carnivals had their place. Revolution wanted to get rid of theater, even art as such: it was a Puritan event. Only after Glorious Revolution theater was allowed inside London's walls. At the same time, it was tamed by architecture and entered its progress towards Italian theater model, where hierarchy of audience put all visitors in their proper places to represent society as such together with social capital and social divides each stratum represented and inhabited. 
Sport, however, remained on the other side of order for quite some time, until the $20^{\text {th }}$ century. And it did change its scope from all kind of activities which were conducted without restraint of public order or realms discipline at the same time. Which means that "sport", at the end of the $19^{\text {th }}$ century even in England could still mean an easy way to understand the laws of mathematics, or, all kinds of activities we call "hobbies" nowadays. What "sport" amounted to was not only physical activity spent in competition, it covered all activities which belonged to leisure time. This, by the way, exemplifies how division of space (territory of order vs. territory of lewdness) turned into division of time (labor time vs. free time), but it also makes visible how architecture entered sport: as one of the tools which had to turn plebeian wild and free entertainment into "fine sport", and at the same time allow for its entrance into organized and supported leisure. Organization of space, which enters theater (earlier) and sport (later) as a result of specific cultural turn from plebeian to fine entertainment is essential for modern society in which people have to be free and under control at the same time. They have to be free because they are expected to appear on the market, at least with their ability to exchange labor for capital, but they also have to be under control even during their free time to make private ownership of the means of production safe.

\section{CONCLUSION}

The process which took sport away from its plebeian roots to produce mass sport recreation and sport mediatization, which put sport under control of international associations turned into capital corporations and which developed sport into global sensation and spectacle is at the same time a process which produced sport architecture as part of global investment in sport economy and in "sportization" of urban environment. That sport turned into profitable business on grand scale and at the same time managed to become grand global spectacle, are the two fundamental moves which changed sport and its architecture during the last fifty years. During this change, it was however most important to keep and even inflate sports' attractiveness, especially media attractiveness, and its "democratic" accessibility to all strata of society, again, especially through media. We remember Walter Benjamin with his claims that masses demand aesthetic pleasure to get as near as possible and that they demand technical reproducibility of aesthetic pleasure and thrill. There is no doubt that these two directions shaped contemporary sport. But, important even in architectural terms: How near is near? To be near represents a break between my body and the object which is near to it: minimal break perhaps but still a break and not immediate access or even a direct touch. It seems that the most important change in sport architecture during the last decades is constant and persistent introduction of 
"break" and "gap" in sports" public space. Spectatorship, obviously, is so different from traditional presence at sport games that it demands a gap between audience and event even if it is near to invisible. And most of the time it is not invisible anyway, quite the contrary, because these breaks and gaps were introduced together with safety concerns so that these obstructions and fences are not just like English garden's "ha-ha" but real and quite visible thing. Those who remember previous arrangements, some fifty years ago, could say that then it was possible for audience and players to get together immediately after the game came to an end. This was sometimes awkward and unwelcome, sometimes even violent but the need to install the line of divide did not burst out just for safety reasons. It was installed to divide two scenes which both became so important for mediatized spectacle: physically present public which embodies representation of all the others who watch without physical presence at the spot of the game and physically present players. The division between media public and live audience demands that this division is enacted to mark the importance of media audience through representation. Masses want their aesthetic pleasure to be as near as possible but not without division: what they want is theatricality, and not (physical) absorption. If we think about the idea behind fan groups, which are something very different from much older supporters of the club, this idea means glorifying your chosen competitor and putting it on the pedestal, not (as it used to be) to become equal immediately after the match, drinking beer together and discussing what went right or wrong. The distancing in nearness, this "having all at a grip of a hand" approach of new media, does not allow for intimate relationship between players and their public. And that it is what contemporary architecture takes care of as well.

Deportation, as original meaning of sport as being deported from realm of imposed rules of behavior (scene) into realm where you can practice what you like (obscene), applies in these new circumstances in reverse direction. Sport has finally become "fine sport" and has been arranged and administered as such. Being simplified and regulated more and more to appeal to Jederman of Media Republic and turned into accessible healthy practices of fitness and wellness (which represent negation of sport as competitive joy and of physical culture as triumph of collectivity), sport is in danger of getting disconnected from its original background in play. What is lacking in precise, efficient and goal-oriented recreation is precisely - playfulness of sport; what is needed in enormously grown and developed system of professional sport, spectacularized and divided from its audience by its architecture, is some real, corporeal and sensual pleasure and less of distant theatricality created by imposed limits of sublime spectacle. Both sport and architecture should not get disconnected from their origin: "It’s about body, stupid!" 
On political impact of Roman games and architecture, including comparison with Greek festivals, see: Paul Plass, The Game of Death in Ancient Rome: Arena Sport and Political Suicide (Madison: The University of Wisconsin Press, 1955). Famous Juvenal's accusation or Roman plebs whose communal desire was reduced to »panem et circenses « (bread and circus) is from his Satire 10 (in Latin - http://www.thelatinlibrary.com/juvenal/10.shtml).

Roman citizenship was given to all free male subjects of empire by Caracalla with his Constitutio Antoniana in 212.

On Roman hegemony in spectacles, see my article »Tertullian i Hegelova romantičarska forma umetnosti«, TkH, 3(6), 2003, 69-81. podvala »božanskog Barona» Pjera de Kubertena (Nikšić: Univerzitetska riječ, 1988) and Ljubodrag Simonović, Filozofski aspekti modernog olimpizma (Beograd: Simonović, 2009). Another and similar case against Olympic games can be found in works of Jean-Marie Brohm, especially in. Jean-Marie Brohm, 1936: Les Jeux olympiques á Berlin (Bruxelles: André Versaille, 2008). and Jean-Marie Brohm, La Tyrannie sportive: Théorie critique d'un opium du peuple (Paris: Beauchesne, 2006).

On May 25 festival, see: "Lev Kreft, Days of Youth: Political Aesthetics and Physical Culture," in Sporting Reflections: Some Philosophical Perspectives, ed. Sheridan H., L. Howe and K.

Thompson (Oxford: Meyer\&Meyer Sport, 2007), 8-19.

Charles Jencks is one of most outstanding architectural theorists of post-modern architecture, starting from global bestseller The Language of Post-Modern Architecture (NY: Rizzoli, 1977). His influence on theories of post-modernism, and of contemporary architecture is quite substantial. In relation to difference between modernism and post-modernism, Jencks belongs to those who see post-modernism as another kind of modernism.

For two typical cases on this fear of the masses which are inevitable component of modern life, see: Gustave Le Bon, La Psychologie des foules (1895), available at: http:/envole.net/enote/ doc/20080418-Gustave-le-bon-psycho-des-foules-alcan.pdf, and in translation as Psihologija gomila (Beograd and Čačak: Kukić and Gradac, 2007). Ortega y Gasset, The Revolt of the Masses (1930), available at http://pinkmonkey.com/library1/revolt/pdf. Preciado, Pornotopía: Arquitectura y sexualidad en "Playboy" durante la guerra fría (Barcelona: Anagrama, 2010).

On the impact of masses on culture, see: Walter Benjamin, Eseji (Beograd: Nolit, 1974). especially his essay »The Work of Art in the Age of Mechanical Reproduction«, which can be accessed in English at: http://design.wishiewashie.com/HTS/WalterBenjaminTheWorkofArt.pdf. 
Benjamin, Walter. "Umetničko delu u veku svoje tehničke reprodukcije," u Eseji, Beograd: Nolit, 1974, 114-149.

Benjamin,Walter, "The Work of Art in the Age of Mechanical Reproduction", available at http:// design.wishiewashie.com/HTS/WalterBenjaminTheWorkofArt.pdf (8.11.2012).

Brohm, Jean-Marie. La Tyrannie sportive: Théorie critique d'un opium du peuple. Paris: Beauchesne, 2006.

Brohm, Jean-Marie. 1936: Les Jeuy olympiques á Berlin. Bruxelles: Andreé Versailles, 2008.

Ortega y Gasset, The Revolt of the Masses (1930), available at http://pinkmonkey.com/library1/ revolt/pdf.

Jencks, Charles. The Language of Post-Modern Architecture. New York: Rizzoli, 1977.

Juvenal,"Satire", available at http://www.thelatinlibrary.com/juvenal/10.shtml (8.11.2012)

Kreft, Lev."Tertullian i Hegelova romantičarska forma umetnost," TkH, 3(6), 2003, 69-81.

Lev Kreft, "Days of Youth: Political Aesthetics and Physical Culture," Sporting Reflections: Some Phylosophycal Perspectives (ed. Sheridan H., Howe L. And K. Thompson), Oxford: Meyer\&Meyer Sport, 2007, 8-19.

Gustave Le Bon, La Psychologie des foules (1895), accessible at http:/envole.net/enote/ doc/20080418-Gustave-le-bon-psycho-des-foules-alcan.pdf (8.11.2012)

Le Bon, Gustave. Psihologija gomila, Beograd and Čačak: Kukić and Gradac, 2007.

Plass, Paul. The Game of Death in Ancient Rome: Arena Sport and Political Suicide. Madison: The University of Wisconsin Press, 1955.

Preciado, Beatrox. Pornotopía: Arquitectura y sexualidad an »Playboy« durante la guerra ftía. Barcelona: Anagrama, 2010

Simonović, Ljubodrag. Olimpijska podvala »božanskog Barona« Pjera de Kubertena. Nikšić: Univerzitetska riječ, 1988.

Simonović,Ljubodrag. Filozofski aspekti modernog olimpizma. Beograd: Simonović, 2009. 
"teoretizacija" u vremenu poznog modernizma i postmoderne kulture. Kazuje se na modalitete teorije izvan filozofije i estetike. Približavaju se diskursi iz filozofije, humanističkih nauka, slobodnih teoretizacija i arhitektonskih teorija. U završnom potpoglavlju se razmatra status savremene filozofije i savremene arhitekture. Posebno se razrađuje pojamj savremenosti. Centralna teza ovog rada je da je odnos arhitektiure i filozofije tj. teorije konstitutivan za modernu, postmodernu i savremenu arhiutekturu. Izvedena teza rasprave je da kritička teorija arhitekture i arhitektonska žudnja za "kritičkom arhitekturom" su dobile izuzetan značaj u vremenu globalnih konflikta i, danas, u vremenu globalne ekonomske krize. Teorijska, estetička i filozofska pažnja se suštinski pomerila pomerila sa imanentnih pitanja o arhitekturi (forma, funkcija, spektakularnost) na spoljašnja tj. transcendentna pitanja o kulturi i društvu, tj. o ekonomiji, moći, upravljanju, nadzoru, oblicima života, fleksibilnosti arhitektonske proizvodnje, razmene i potrošnje.

KLJUČNE REČI: ARHITEKTURA, FILOZOFIJA, ESTETIKA, TEORIJA, HUMANISTIKA, ZNANJE, VREME TORIJE, SAVREMENOST, SAVREMENA ARHITEKTURA

ARHITEKTURA KROZ SPORT

\section{Lev Kreft}

Može se naći određena paralela između arhitekture i sporta u istoriji (Rim) i savremenom dobu koje nosi sportski spektakl kao globalno najveći vid zabave, i prepoznatljive arhitekture sporta kao znaka njegovog opšteg prisustva. Olimpijske igre 2012.g. u Londonu pratile su slogan „Arhitektura za čovečanstvo", dodajući ekološku i društvenu zabrinutost tradicionalnoj ideji sportskih objekata kao modernih katedrala. Arhitektura sporta postala je iskaz koji otelovljuje ideologiju koja sport pretvara u razlog nadanja. Arhitektura sporta nastala je u polju u kom standardizacija prostora (i vremena) postoji više od sto godina, zajedno sa koncentracijom moći u sportskim udruženjima koja su, tokom ovih sto godina, promenila svoj identitet iz pokreta civilnog društva u institucije kapitalizma. Originalno značenje ,sporta“ (desportes, deport) kao aktivnosti van redovnog i uobičajenog svakodnevnog života produženo je u nove domene prostora i vremena u kojima se proizvodi zabava masovnih medija. Savremena arhitektura sporta mora da prati posebna prostorna pravila i zahteve sportskih igrališta i pravila medijskog prisustva. Mesta sporta su mesta gde masivna publika gleda utakmicu i gde posmatra sebe kako posmatra - biti viđen od strane mase čije je virtuelno prisustvo danas možda najvažniji interes projektovanja arhitekture sporta. 